\title{
Reduction in Plasma Human Immunodeficiency Virus Ribonucleic Acid after Dideoxynucleoside Therapy as Determined by the Polymerase Chain Reaction
}

\author{
Mark Holodniy, David A. Katzenstein, Dennis M. Israelski, ${ }^{\star}$ and Thomas C. Merigan \\ Center for AIDS Research, Stanford University Medical Center, Stanford, California 94305; \\ and ${ }^{\ddagger}$ San Mateo County AIDS Program, San Mateo, California 94403
}

\begin{abstract}
Cell-free HIV RNA in plasma was detected and quantitated after antiviral therapy by the polymerase chain reaction. RNA was extracted from plasma, reverse transcribed to cDNA, amplified by polymerase chain reaction, and quantitated by absorbance based on an enzyme-linked affinity assay. 72 HIV antibody-positive subjects had one plasma sample taken. 39 who were not receiving antiretroviral therapy at the time had a mean plasma HIV RNA copy number of $690 \pm 360$ (mean \pm SEM) per $200 \mu l$ of plasma, while 33 subjects who had been receiving zidovudine therapy for a minimum of 3 mo had a mean copy number of $134 \pm 219(P<0.05)$.

27 additional HIV antibody-positive patients had two plasma samples taken before and 1 mo after initiating dideoxynucleoside therapy. Plasma HIV RNA copy number fell from $540 \pm 175$ to $77 \pm 35(P<0.05)$. Finally, nine of these subjects had two baseline samples obtained before initiating therapy and two posttreatment samples 1 and 2 mo after therapy was begun. Mean plasma RNA copy number declined from $794 \pm 274$ to $<40$ (below the lower limit of sensitivity) after 1 mo of therapy, with suppression maintained after 2 mo of therapy.

These results suggest that gene amplification can be used to detect and quantitate changes in plasma HIV RNA after dideoxynucleoside therapy. Plasma HIV polymerase chain reaction may be a more sensitive marker to monitor antiviral therapy, particularly in asymptomatic patients where measurement of p24 antigen or quantitative plasma cultures are negative. ( $J$. Clin. Invest. 1991. 88:1755-1759.) Key words: AIDS • gene amplification $\bullet$ cDNA $\bullet$ zidovudine $\cdot$ antiviral
\end{abstract}

\section{Introduction}

The ability to detect and quantitate circulating virus in patients infected with the HIV has largely been studied by culture of infectious virus, either from circulating peripheral blood mononuclear cells or cell-free plasma $(1,2)$. Several studies have shown that infectious virus titers correlate with stage of disease

Address correspondence to Mark Holodniy, M.D., Center for AIDS Research, Room S-156, Stanford University Medical Center, Stanford, CA 94305.

Received for publication 14 May 1991.

J. Clin. Invest.

(C) The American Society for Clinical Investigation, Inc.

$0021-9738 / 91 / 11 / 1755 / 05 \$ 2.00$

Volume 88, November 1991, 1755-1759
(1-3) and are high in acute infection (4). One study has also suggested that plasma virus titer, as measured by quantitative culture, decreases with antiretroviral therapy (1).

Gene amplification by the polymerase chain reaction $(P C R)^{1}$ has been widely used for the detection, and, to a lesser degree, quantification of circulating HIV nucleic acid. PCR has been used to detect HIV proviral DNA in peripheral blood mononuclear cells as a marker of HIV disease progression (5) or as a measure of effectiveness of antiretroviral therapy (6) and (6a). Cellular HIV RNA has also been detected by PCR after reverse transcription in PBMC as a more specific measure of HIV replication events (7). In addition, HIV RNA has been detected in cell-free plasma or serum of HIV infected subjects. HIV RNA has been detected in the plasma of patients before and after acute seroconversion (8), in serum related to stage of disease (9), in seropositive hemophiliacs (10), and in plasma related to stage of disease and use of antiviral therapy (11). In one study, a decrease in circulating plasma HIV nucleic acid was found after passive immunotherapy with anti-HIV immunoglobulin (12). However, it is unclear whether cell-free plasma HIV RNA can be used as a marker of viral load after dideoxynucleoside therapy.

In the present study, we determined that plasma HIV RNA copy number can be quantitated and does decrease during dideoxynucleoside therapy.

\section{Methods}

Patients. After informed consent was obtained, whole blood samples were collected by venipuncture in the presence of acid-citrate-dextrose as an anticoagulant. A single plasma sample was collected from $39 \mathrm{HIV}$ antibody-positive subjects who were not receiving antiretroviral therapy at the time of collection and from $33 \mathrm{HIV}$ antibody-positive subjects who were currently on and had received zidovudine (ZDV) for a minimum of $3 \mathrm{mo}$.

Two plasma samples were collected from an additional 27 subjects before and $1 \mathrm{mo}$ after initiation of dideoxynucleoside therapy. 18 of these subjects received $500 \mathrm{mg} / \mathrm{d}$ of zidovudine orally. Seven subjects received a combination of zidovudine $(150-600 \mathrm{mg} / \mathrm{d})$ and $2^{\prime}, 3^{\prime}-$ dideoxyinosine (ddI) $(134-500 \mathrm{mg} / \mathrm{d})$. Two patients received $500 \mathrm{mg} / \mathrm{d}$ of ddI alone (see Table I for individual subject characteristics). Finally, nine of these subjects had two plasma samples taken 1-3 wk before initiating antiretroviral therapy and two plasma samples taken 1 and 2 mo after commencing therapy. Plasma was separated within $4 \mathrm{~h}$ by centrifugation at $500 \mathrm{~g}$ for $10 \mathrm{~min}$. A second centrifugation was per-

1. Abbreviations used in this paper: ddI, 2',3'-dideoxyinosine; HRP, horseradish peroxidase; PCR, polymerase chain reaction; ZDV, zidovudine. 
Table I. Clinical Parameters and PCR Analysis of Plasma HIV RNA from 27 Patients

\begin{tabular}{|c|c|c|c|}
\hline Patient no. & $\begin{array}{l}\text { Antiviral } \\
\text { treatment }\end{array}$ & Pre/post CD4 & Pre/post HIV RNA \\
\hline & & cells $/ \mathrm{mm}_{3}$ & copy number $/ 200 \mu l$ \\
\hline $1^{*}$ & $\mathrm{ZDV}^{\ddagger}$ & $647 / 561$ & $106 / 90$ \\
\hline $2^{*}$ & ZDV & $541 / 651$ & $130 / 0$ \\
\hline 3 & ZDV & $840 / 874$ & $550 / 0$ \\
\hline 4 & ZDV & $432 / 462$ & $100 / 77$ \\
\hline $5^{*}$ & ZDV & $379 / 415$ & $87 / 57$ \\
\hline $6^{*}$ & ZDV & $428 / 408$ & $40 / 42$ \\
\hline 7 & ZDV & $422 / 345$ & $94 / 94$ \\
\hline 8 & ZDV & $420 / 402$ & $0 / 0$ \\
\hline 9 & ZDV & $432 / 532$ & $93 / 65$ \\
\hline 10 & ZDV & $430 / 430$ & $105 / 52$ \\
\hline 11 & ZDV & $429 / 404$ & $123 / 50$ \\
\hline 12 & $\mathrm{ddI}+\mathrm{ZDV}^{\S}$ & $280 / 220$ & $526 / 0$ \\
\hline 13 & ZDV & $323 / 320$ & $78 / 45$ \\
\hline 14 & ZDV & $320 / 456$ & $95 / 95$ \\
\hline 15 & ZDV & $353 / 387$ & $301 / 0$ \\
\hline 16 & $\mathrm{ddI}+\mathrm{ZDV}^{\S}$ & $309 / 399$ & $300 / 0$ \\
\hline 17 & $\mathrm{ddI}+\mathrm{ZDV}^{\S}$ & $337 / 398$ & $260 / 0$ \\
\hline 18 & ddI" & $328 / 310$ & $966 / 0$ \\
\hline 19 & ddI + ZDV & $383 / 491$ & $245 / 0$ \\
\hline 20 & ZDV & $404 / 413$ & $0 / 0$ \\
\hline 21 & ZDV & $270 / 450$ & $958 / 72$ \\
\hline 22 & ddI + ZDV' & $292 / 344$ & $60 / 0$ \\
\hline 23 & ZDV & $320 / 295$ & $2769 / 437$ \\
\hline 24 & ddIII & $222 / 370$ & $3944 / 0$ \\
\hline 25 & ZDV & $568 / 732$ & $2014 / 925$ \\
\hline 26 & ddI $+Z D^{* *}$ & $367 / 473$ & $217 / 0$ \\
\hline 27 & ddI $+Z^{2 D V^{* *}}$ & $310 / 399$ & $439 / 0$ \\
\hline
\end{tabular}

* Remote history of ZDV use.

₹ ZDV dose $500 \mathrm{mg} / \mathrm{d}$ unless otherwise stated.

ZDV $300 \mathrm{mg} / \mathrm{d}+$ ddI $334 \mathrm{mg} / \mathrm{d}$.

" ddI $500 \mathrm{mg} / \mathrm{d}$.

' ZDV $600 \mathrm{mg} / \mathrm{d}+$ ddI $500 \mathrm{mg} / \mathrm{d}$.

** ZDV $150 \mathrm{mg} / \mathrm{d}+$ ddI $134 \mathrm{mg} / \mathrm{d}$.

formed on the plasma at $500 \mathrm{~g}$ for $30 \mathrm{~min}$ to remove any cellular material. $200 \mu$ l of plasma was then mixed with $200 \mu$ l of a solution containing $5 \mathrm{M}$ guanidinium thiocyanate, vortexed briefly, and stored at $-70^{\circ} \mathrm{C}$ until further use. All samples were assayed within 3 mo of collection. To decrease variance, all specimens to be compared from the same subject were run in the same assay.

Extraction of RNA from plasma. RNA was extracted from plasma by a previously described method (13). Briefly, $200 \mu \mathrm{l}$ of clarified plasma to which $200 \mu$ l of $5 \mathrm{M}$ guanidinium thiocyanate had previously been added was extracted with phenol/chloroform and precipitated with isopropanol. The resulting pellet was then washed in $75 \%$ ethanol, dried, and brought up in diethylpyrocarbonate-treated glass distilled water.

Reverse transcription and amplification of $c D N A$. HIV RNA was transcribed to cDNA using Moloney murine leukemia virus reverse transcriptase (Bethesda Research Laboratories, Gaithersburg, MD) by a previously described method (14). Oligomers used for amplification included SK38, SK39, and SK19, all of whose sequences have been published previously (15). Biotinylation of SK38 and horseradish peroxidase (HRP) labeling of probe SK 19 were prepared as described (16).

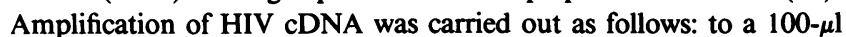

reaction mixture was added the cDNA, 50 pmol of primers SK38 and SK39, $10 \mathrm{mM}$ of each dNTP, $10 \mathrm{mM}$ Tris (pH 8.3), $2.5 \mathrm{mM} \mathrm{MgCl}_{2}, 50$ $\mathrm{mM} \mathrm{KCl}$, and $2.5 \mathrm{U}$ of recombiTaq DNA polymerase (Perkin-Elmer Cetus, Norwalk, CT). The mixture was then overlaid with $50 \mu \mathrm{l}$ of mineral oil. Tubes were placed in a DNA thermal cycler (Perkin-Elmer Cetus) for 30 cycles of amplification with the following program: $95^{\circ} \mathrm{C} /$ $30 \mathrm{~s}, 55^{\circ} \mathrm{C} / 30 \mathrm{~s}$, and $72^{\circ} \mathrm{C} / 60 \mathrm{~s}$ for denaturation, annealing, and extension, respectively. Negative and positive controls which included both high and low copy number HIV RNA and DNA were added at each step.

Enzyme-linked affinity assay. To detect and quantitate PCR product, 96-well microplates (Maxisorp; Nunc, Naperville, IL) were coated with $100 \mu \mathrm{l}$ of a $0.1-\mathrm{mg} / \mathrm{ml}$ solution of avidin (Sigma Chemical Co., St. Louis, $\mathrm{MO}$ ) in $50 \mathrm{mM} \mathrm{Na}_{2} \mathrm{CO}_{3}$ (pH 9.6) overnight at room temperature. Wells were then washed twice with PBS. Wells were then filled with $300 \mu$ l of a blocking solution containing $5 \times$ Denhardt's solution, $1 \%$ gelatin (Sigma), $250 \mu \mathrm{g} / \mathrm{ml}$ sheared herring sperm DNA (Promega Biotec, Madison WI) at least overnight at $4^{\circ} \mathrm{C}$. Immediately before use, the blocking solution was aspirated from each well and $5 \mu$ l of PCR product and $65 \mu \mathrm{l}$ of a hybridization solution, containing $5 \times$ saline sodium phosphate EDTA, $5 \times$ Denhardt's solution, and 1 pmol of HRP-labeled SK19 HIV gag specific probe was added to each well. A capture and hybridization reaction was then carried out in the well for $1 \mathrm{~h}$ at $42^{\circ} \mathrm{C}$. The 96-well microplate was then placed in a Biomek ${ }^{\mathrm{m}}$ 1000 Automated Workstation (Beckman Instruments, Inc., Palo Alto, CA) where wells were washed 20 times with PBS containing $0.05 \%$ Tween-20. The HRP substrate $O$-phenylenediamine (Sigma) was prepared at $0.6 \mathrm{mg} / \mathrm{ml}$ in $0.1 \mathrm{M}$ citrate buffer (pH 5.5) containing $0.03 \%$ hydrogen peroxide. $150 \mu \mathrm{l}$ of this substrate solution was added to each well. After 10 min the reaction was stopped with $1 \mathrm{~N} \mathrm{H}_{2} \mathrm{SO}_{4}$ and the optical density of each well measured at $490 \mathrm{~nm}$ by the Biomek 1000 . A lower level of positivity had been previously defined as an absorbance of 0.135 . This cutoff value was calculated from the mean absorbance obtained from a group of seronegative samples plus three standard deviations. Copy number from subject samples were determined from the absorbances obtained from a dilution series of an RNA gag gene construct of known copy number described previously (9). The lower level of sensitivity in this assay was 40 copies of HIV gag gene RNA.

Plasma HIV culture and P24 antigen assay. Quantitative HIV plasma microculture was performed according to the method described by Ho et al. (1). P24 antigen was detected by an antigen capture assay by a method provided by the supplier (Abbott Laboratories, North Chicago, IL).

Statistical analysis. Sample optical density was converted to copy number and analyses performed on samples expressed as RNA copy number $/ 200 \mu$ l of plasma. A $t$ test of independent samples was used in analysis of subjects who did not receive antiretroviral therapy compared to subjects who were receiving zidovudine. A $t$ test of paired samples was used to analyze paired plasma data and CD4 counts from subjects pre- and posttherapy. All $t$ tests were two tailed. A Fisher's exact test or chi square test were used for analysis of proportion where appropriate. Statistical significance was defined as $P<0.05$.

\section{Results}

72 subjects were evaluated in a cross-sectional study of HIV disease to determine plasma HIV RNA copy number by PCR. The results are presented in Fig. 1.39 subjects who were not currently receiving antiretroviral therapy and 33 subjects who were receiving zidovudine were evaluated. Untreated subjects were more likely to have a positive signal than treated subjects ( 32 of 39 vs. 16 of 33, respectively, $P<0.008$, chi square). In the 39 subjects who were not currently receiving therapy, the mean plasma HIV RNA copy number was $690 \pm 360$ (mean \pm SEM) per $200 \mu$ l of plasma, while the 33 subjects who had been receiving zidovudine therapy had a mean copy num- 


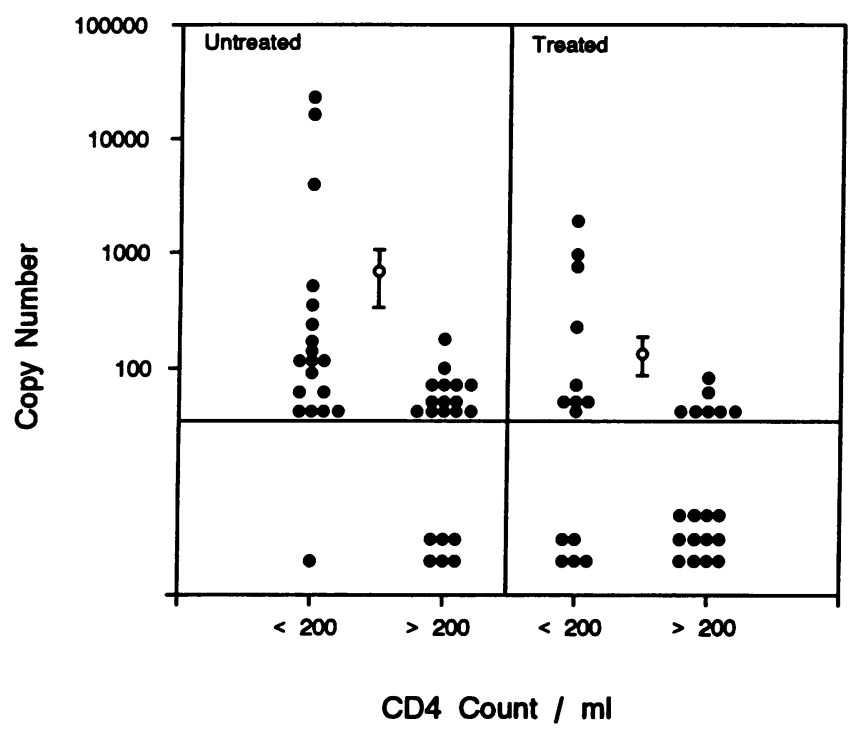

Figure 1. Human immunodeficiency virus RNA copy number in 200 $\mu l$ of plasma from 72 subjects as determined by cDNA gene amplification. Of 39 patients who were not currently receiving antiretroviral therapy, 20 had a CD4 count $<200 / \mathrm{mm}^{3}$ (HIV copy number $1,369 \pm 707$ ) and 19 had a CD4 count $>200 / \mathrm{mm}^{3}$ (copy number $44 \pm 10$ ). Of 33 subjects who were currently on zidovudine, 14 had a CD4 count $<200 / \mathrm{mm}^{3}$ (copy number $295 \pm 5$ ) and 19 had a CD4 count $>200 / \mathrm{mm}^{3}$ (copy number $16 \pm 5$ ). Mean copy number (open circles) of subjects not on therapy was $690 \pm 360$ vs. $134 \pm 219$ for patients currently on zidovudine ( $P<0.05$, independent sample $t$ test).

ber of $134 \pm 219(P<0.05)$. Mean CD4 count for each group was $316 \pm 45$ and $300 \pm 37$, respectively $(P=N S)$.

Subgroups were then analyzed with respect to CD4 count. Among those with $<200$ CD4 cells, untreated subjects were more likely to have positive signal than treated subjects ( 18 of 19 vs. 9 of $14, P<0.04$, Fisher's exact test). Among those with $>200$ CD4 cells, 14 of 20 untreated subjects vs. 7 of 19 treated subjects had a detectable signal ( $P=$ NS, Fisher's exact test). Untreated subjects with CD4 count $<200 / \mathrm{mm}^{3}$ had a mean RNA copy number of $1,369 \pm 707$ and mean CD4 count of $73 \pm 17$; untreated subjects with CD4 $>200 / \mathrm{mm}^{3}$ had a mean RNA copy number of $44 \pm 10$ and mean CD4 count of $547 \pm 45$; treated subjects with CD4 counts $<200 / \mathrm{mm}^{3}$ had a mean RNA copy number of $295 \pm 5$ and mean CD4 count of $115 \pm 13$; and treated subjects with CD4 counts $>200 / \mathrm{mm}^{3}$ had calculated mean RNA copy number of $16 \pm 5$ (which is below the level of detection of this assay and would be interpreted as negative) and mean CD4 count of $437 \pm 41$.

27 additional subjects were then evaluated before and $1 \mathrm{mo}$ after initiation of dideoxynucleoside therapy. Clinical parameters of the subjects are presented in Table I. PCR results are presented in Fig. 2. Results show that plasma HIV RNA copy number fell from $540 \pm 175$ to $77 \pm 35$ after therapy $(P<0.05$, paired $t$ test). Mean CD4 count increased from $399 \pm 24$ to $442 \pm 25$ after 4 wk of therapy $(P<0.006$, paired $t$ test). Although subjects received ZDV or ddI alone or in combination, there were not enough subjects to comparatively evaluate antiviral efficacy of ddI alone or combination regimens.

Finally, 9 of the 27 subjects had two samples taken before initiation of therapy and two samples taken 1 and 2 mo after commencing therapy. The results are presented in Fig. 3. When

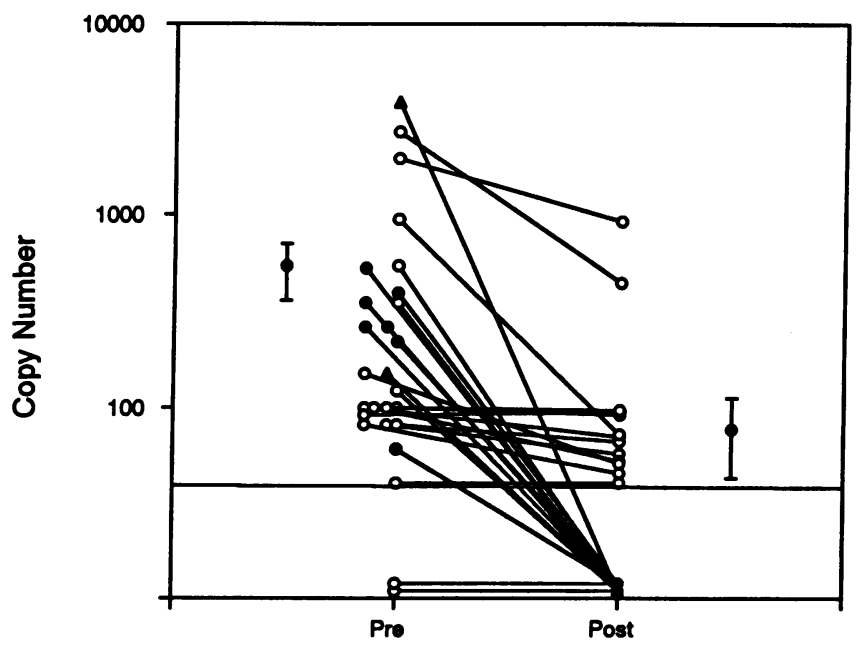

Figure 2. Human immunodeficiency virus RNA copy number in plasma from 27 subjects before (pre) and 1 mo after (post) dideoxynucleoside therapy. (0) ZDV; (๑) ZDV + ddI; and ( $)$ ddI alone. Mean copy number decreased from $540 \pm 175$ to $77 \pm 35$ after therapy $(P$ $<0.05$, paired $t$ test).

two pretherapy time points were analyzed for constancy of signal, results show that mean copy number for each pretherapy time point was $945 \pm 377$ and $643 \pm 392$.

Two subjects had a second pretherapy sample which was negative. When both pretherapy copy number values were compared to posttherapy values, plasma HIV RNA copy number fell from $794 \pm 274$ to $<40$ (which is below the lower level of detection in this assay) after 1 and 2 mo of therapy $(P<0.05$, paired $t$ test). Mean CD4 count increased from $314 \pm 15$ to $378 \pm 25(P<0.05$, paired $t$ test $)$.

Plasma culture was performed on fresh material obtained from the initial pretreatment sample from 23 of 27 of these patients. Only 7 of 23 were plasma virus positive by culture (from 1 to 100 tissue culture infective dose/ml). All 23 of these

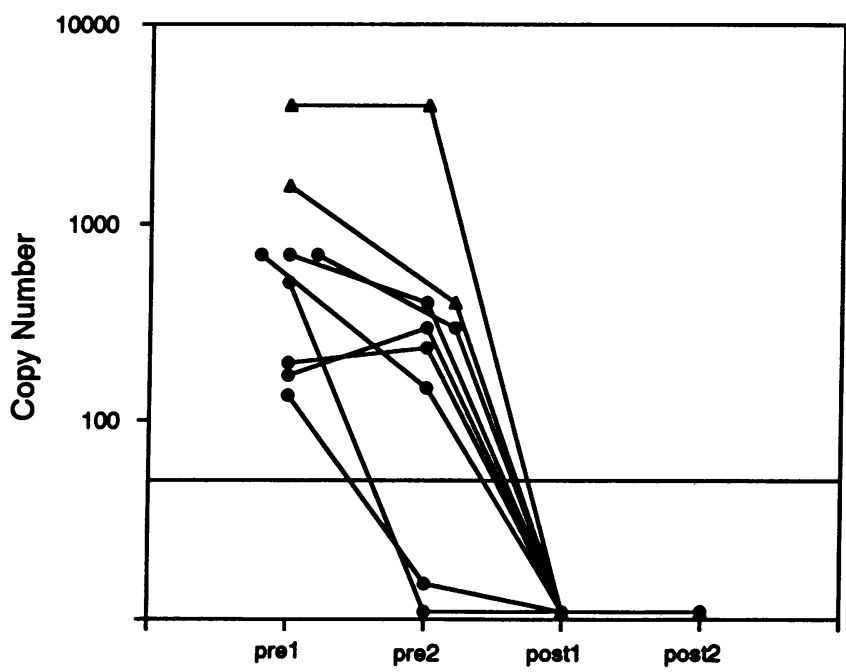

Figure 3. Human immunodeficiency virus RNA copy number in plasma from 9 subjects with two samples obtained before initiation of therapy (pre1 and pre2) and two samples obtained 1 and 2 mo

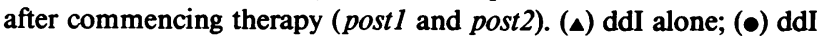
+ ZDV. 
patients were positive by PCR ( $>40$ copies $/ 200 \mu \mathrm{l}$ ). In addition, a p24 antigen test was performed on all 27 pretreatment samples. Only 2 of 27 had detectable p 24 antigen present ( $>30$ $\mathrm{pg} / \mathrm{ml})$.

\section{Discussion}

The results presented here demonstrate that plasma HIV RNA can be detected and quantified by copy number in the majority of patients infected with HIV. In addition, plasma HIV RNA copy number could serve as a marker of circulating HIV viral load to assess treatment effect of dideoxynucleoside compounds and other potential antiretroviral compounds. We initially conducted a survey to determine whether treatment or degree of immunologic impairment, based on CD4 count, affected plasma HIV RNA copy number. Untreated patients as a group had higher copy numbers than treated patients. Untreated patients with $<200 \mathrm{CD} 4$ cells $/ \mathrm{mm}^{3}$ had a higher mean copy number than patients with $>200 \mathrm{CD} 4$ cells $/ \mathrm{mm}^{3}$. Likewise, treated patients with $<200 \mathrm{CD} 4$ cells $/ \mathrm{mm}^{3}$ had higher copy numbers than patients with $>200 \mathrm{CD} 4$ cells $/ \mathrm{mm}^{3}$, suggesting that patients with more advanced HIV disease have higher circulating copy numbers than asymptomatic patients, and that the antiretroviral benefit seen in patients with higher CD4 counts may be waning.

To assess the short-term impact of antiretroviral therapy on patients, 27 patients were evaluated before and 1 mo after initiation of ZDV, ddI, or combination therapy. As CD4 counts increased after 1 mo of therapy, HIV RNA copy number fell significantly. However, the response of individual subjects was variable. 16 of 27 subjects had a marked decrease in copy number and 11 of 27 did not. Because the majority of subjects received ZDV alone, it was not possible to assess any differences between $\mathrm{ZDV}$, ddI, or combination regimens.

Finally, nine subjects had two baseline time points taken in the 3 wk before treatment, followed by two monthly samples posttreatment. Pretreatment signal was constant in 7 of 9 subjects, and 2 subjects had discordant samples, i.e., one was positive and one was negative. This could be related to real changes in circulating HIV RNA, or introduced during sample collection, handling, or the assay. However, pretherapy and posttherapy samples were run in the same assay and so were subject to all of the same reaction conditions. When sample positivity was considered in relation to therapy, 16 of 18 pretherapy samples had a positive signal vs. 0 of 18 posttherapy samples $(P$ $<0.001$, chi square) showing suppression of HIV RNA copy number with treatment.

Currently there is no standard method to assess circulating viral load in all HIV-infected patients. Plasma viremia, measured by quantitative microculture, can identify and quantify infectious virus in $50-100 \%$ of patients, principally those with advanced stages of HIV disease, low CD4 counts, and p24 antigenemia (1-3). Many patients with $>200 \mathrm{CD} 4$ cells $/ \mathrm{mm}^{3}$ do not have detectable infectious plasma viremia. This may be due to an absence of circulating infectious virus, virus which is neutralized by specific antibody, or the insensitivity of culture techniques. The results presented here suggest that the majority of patients with $>200 \mathrm{CD} 4$ cells $/ \mathrm{mm}^{3}$ do not have plasma p24 antigen or infectious virus detectable by culture techniques. However, all of these patients have HIV RNA in their plasma which can be detected and quantitated by PCR.
Attempts have been made to assess HIV viral load in patients by molecular techniques, mainly by quantitative PCR of HIV proviral DNA in circulating mononuclear cells or cell-free virion-associated RNA in plasma. Published data suggest that the number of cells infected with HIV increases with advancing disease and that HIV proviral DNA content increases as well. We and others have shown a decrease in HIV proviral DNA with dideoxynucleoside therapy over time $(6,6 \mathrm{a})$. This was not the case in another published small series (17).

We have previously shown that HIV RNA could be quantified in serum and that copy number increased with disease progression (9). Plasma HIV RNA has been shown to be present before and after seroconversion with quantitative decreases occurring after seroconversion (8). The recent report by Daar et al. (4), showed a decrease in both plasma viremia and proviral DNA from PBMC, coinciding with seroconversion after acute infection. In one report, plasma HIV RNA levels fell with passive immunoglobulin therapy, suggesting a therapy-based response in circulating HIV RNA load (12). Ottman and colleagues have been successful in detecting HIV RNA in plasma from $95 \%$ of patients evaluated (11). They also studied a group of patients who were receiving ZDV to determine whether there was any therapeutic impact on HIV RNA signal. 24 of 25 patients who were receiving ZDV had detectable signal. However, methodological differences in that study vs. the present study may have contributed to the differences noted between them. First, Ottman et al. used an ultracentrifugation step to sediment virus, enhancing virion-associated RNA recovery. Second, 40 cycles of amplification after reverse transcription were performed, which would certainly increase the sensitivity of such an assay to successfully detect HIV RNA in virtually all patients. Although sensitivity is increased with increased cycle number, thus detecting signal in virtually all patients, the ability to show the quantitative changes demonstrated here with 30 cycles of amplification is lost.

We have previously shown in serum that quantitative serum cultures were negative in the majority of patients with $>200 \mathrm{CD} 4 \mathrm{cells} / \mathrm{mm}^{3}$ (9). This is consistent with previously published data. In the current study, 23 plasma samples were evaluated by culture and PCR. All had detectable plasma HIV RNA by PCR, but only seven were plasma HIV-culture positive. Other published experience comparing plasma HIV culture and PCR of HIV RNA from plasma is lacking. Ottmann et al. tested only two patients, both of whom were positive in both assays. Coyle et al. reported that 14 of 20 patients had positive plasma cultures and 12 of 20 patients had detectable HIV RNA in plasma, but no information was given regarding concordance or discordance of samples (10).

The type of plasma sample and method of processing and storage were found to be very important. This is especially germane if an assay of this nature were to be considered for widespread use. The type of anticoagulant used for sample collection can affect detection of plasma RNA. We have previously shown that plasma collected in the presence of heparin does not allow detection of signal because of an inhibitory effect of heparin on gene amplification (18). Although Coyle et al. (10) found detectable signal from plasma collected in the presence of heparin, an ultracentrifugation step preceding RNA analysis lead to removal of most of the heparin from the enzyme-mediated assay system. However, no comparison experiments among anticoagulants were performed to demonstrate any attenuation of signal obtained in the presence of heparin. 
Because of our concern for RNA degradation during specimen storage and freeze thawing, we decided to store fresh plasma at $-70^{\circ} \mathrm{C}$ in the presence of guanidinium and process samples within 3 mo of collection. Samples were stored in guanidinium for RNAase inhibition. Preliminary data from our laboratory would suggest that plasma HIV RNA signal decays with time in the absence of this RNA stabilizer.

In summary, we have shown that plasma HIV RNA copy number can be quantitated by PCR and does decrease with dideoxynucleoside therapy. The nonisotopic, microplatebased format presented here makes it possible to process multiple patient samples with replicates in a single amplification and assay run. Further studies will be required to determine: $(a)$ if long-term suppression of plasma HIV RNA copy number can be maintained during therapy; $(b)$ whether return of or increase in HIV RNA copy number can predict drug failure or disease progression; $(c)$ what, if any, short-term variability is present in RNA signal from treated and untreated patients; and $(d)$ specimen handling requirements necessary for short-term or longterm preservation of plasma RNA to establish the use of this assay in large multicenter clinical trials.

\section{Acknowledgments}

We wish to thank Larry Mole, Jeff Bubp, and Dr. Jeffrey Fessel for their contribution in obtaining samples and patient demographic data collection. We also wish to thank the Cetus Corporation for kindly providing HRP-labeled SK 19.

This work was funded by a grant from the United States Public Health Service (AI-27762-01).

\section{References}

1. Ho, D. D., T. Moudgil, and M. Alam. 1989. Quantitation of human immunodeficiency virus type 1 in the blood of infected persons. N. Engl. J. Med. 321:1621-1625.

2. Coombs, R. W., A. C. Collier, J. P. Allain, B. Nikora, M. Leuther, G. F. Gjerset, and L. Corey. 1989. Plasma viremia in human immunodeficiency virus infection. N. Engl. J. Med. 321:1626-1631.

3. Ehrnst, A., A. Sonnerborg, S. Bergdahl, and O. Strannegard. 1988. Efficient isolation of HIV from plasma during different stages of HIV infection. J. Virol. Methods. 26:23-32.

4. Daar, E. S., T. Moudgil, R. D. Meyer, and D. D. Ho. 1991. Transient high levels of viremia in patients with primary human immunodeficiency virus type 1 infection. N. Engl. J. Med. 324:961-964.

5. Schnittman, S. M., J. J. Greenhouse, M. C. Pallidopoulos, M. Baseler, N. P.
Salzman, A. S. Fauci, and H. C. Lane. 1990. Increasing viral burden in CD4+ T cells from patients with human immunodeficiency virus (HIV) infection reflects rapidly progressive immunosuppression and clinical disease. Ann. Intern. Med. 113:438-443.

6. Aoki, S., R. Yarchoan, R. V. Thomas, J. M. Pluda, K. Marczyk, S. Broder, and H. Mitsuya. 1990. Quantitative analysis of HIV-1 proviral DNA in peripheral blood mononuclear cells from patients with AIDS and ARC: decrease of proviral DNA content following treatment with 2',3'-dideoxyinosine (ddI). AIDS Res. Hum. Retroviruses. 6:1331-1339.

6a. Clark, A. G. B., M. Holodniy, D. H. Schwartz, D. A. Katzenstein, and T. C. Merigan. 1991. Decrease in HIV provirus in peripheral blood mononuclear cells during zidovudine and human rIL-2 administration. J. Acquired Immune Defic. Syndr. In press.

7. Hart, C., T. Spira, J. Moore, J. Sninsky, G. Schochetman, A. Lifson, J. Galphin, and C. Y. Ou. 1988. Direct detection of HIV RNA expression in seropositive subjects. Lancet. ii:596-599.

8. Hewlett, I. K R A. Gregg, C. Y Ou, C. A. Hawthorne, R. E Mayner, R. T. Schumacher, G. Schochetman, and J. S. Epstein. 1988. Detection in plasma of HIV-1 specific DNA and RNA by polymerase chain reaction before and after seroconversion. J. Clin. Immunoassay. 11:161-164.

9. Holodniy, M., D. A. Katzenstein, S. Sengupta, A. W. Wang, C. Casipit, D. H. Schwartz, M. Konrad, E. Groves, and T. C. Merigan. 1991. Detection and quantification of human immunodeficiency virus RNA in patient serum using the polymerase chain reaction. J. Infect. Dis. 163:862-866.

10. Coyle, T., M. Rupert, C. Stephens, B. Jones, L. Zaumetzer, S. O'Lear, and B. Poiesz. 1990. Detection of human immunodeficiency virus in plasma by RNA directed polymerase chain reaction. Clin. Res. 38:778a. (Abstr.)

11. Ottmann, M., P. Innocenti, M. Thenadey, M. Micoud, F. Pelloquin, and J. M. Seigneurin. 1991. The polymerase chain reaction for the detection of HIV-1 genomic RNA in plasma from infected individuals. J. Virol. Methods. 31:273284.

12. Karpas, A., I. K. Hewlett, F. Hill, J. Gray, N. Byron, D. Gilgen, V. Bally, J. K. Oates, B. Gazzard, and J. E. Epstein. 1990. Polymerase chain reaction evidence for human immunbodeficiency virus 1 neutralization by passive immunization in patients with AIDS and AIDS-related complex. Proc. Natl. Acad. Sci. USA. 87: 7613-7617.

13. Chomczynski, P., and N. Sacchi. 1987. Single step method of RNA isolation by acid guanidinium thiocyanate-phenol-chloroform extraction. Ann. Biochem. 162:156-159.

14. Kawasaki, E. S. 1990. Amplification of RNA. In PCR Protocols: A Guide to Methods and Applications. M. A. Innis, D. H. Gelfand, J. J. Sninsky, and T. J. White, editors. Academic Press, Berkeley, CA. 21-27.

15. Kellog, D. E., and S. Kwok. 1990. Detection of human immunodeficiency virus. In PCR Protocols: A Guide to Methods and Applications. M. A. Innis, D. H. Gelfand, J. J. Sninsky, and T. J. White, editors. Academic Press, Berkeley, CA. 337-347.

16. Levenson, C., and C. Chang. 1990. Nonisotopically labeled probes and primers. In PCR Protocols: A Guide to Methods and Applications. M. S. Innis, D. H. Gelfand, J. J. Sninsky, and T. J. White, editors. Academic Press, Berkeley, CA. 99-112.

17. McElrath, M. J., R. M. Steinman, and Z. A. Cohn. 1991. Latent HIV-1 infection in enriched populations of blood monocytes and $T$ cells from seropositive patients. J. Clin. Invest. 87:27-30.

18. Holodniy, M., S. Kim, D. A. Katzenstein, M. Konrad, E. Groves, and T. C. Merigan. 1991. Inhibition of human immunodeficiency virus gene amplification by heparin. J. Clin. Microbiol. 29:676-679. 